\title{
Viticulture in the context of historical landscape structure in the Small Carpathian region - model area of Rača
}

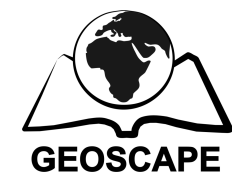

\author{
Rastislav Krivosudský* \\ Department of Landscape Ecology, Faculty of Natural Sciences \\ Comenius University \\ Mlynska dolina, 84215 Bratislava, Slovakia \\ *krivosudsky@fns.uniba.sk
}

\begin{abstract}
The development of viticulture and wine producing has brought forward some unique elements of cultural land and introduced culture itself into the landscape. This culture has affected lives of many generations and determined the development of the society and the living environment. The form, the shape and the type of use of the respective elements of landscape structure has changed according to the change in technology, cultivation processes, orientation of production and the value system of the society. However, the recent viticultural rural land (together with residual areas of historical structure elements) in the vicinity of the capital city of Slovakia - Bratislava - has been under growing pressure caused by suburbanisation. This pressure directly threatens the existence of this kind of landscape and causes irreversible changes to landscape character. Landscape ecologists and architects have to face the issue of how to identify the valuable characteristics of the land and how to protects and keep them for the future generations. The main aim of this paper is to evaluate the role of viticulture in the formation, existence and change of the elements of historical structures of agricultural landscape (HSAL). In addition, this paper presents the layout of various types of these elements, the methodical approach to their mapping and their present status. The results show that out of 141 localities where the HSALs were present in 1951, they could have been located only in 25 localities in 2011. These localities are mainly situated in private properties. However, many of the mapped HSALs are no longer used and in the state of deterioration. The lack of their management gradually causes their demise.
\end{abstract}

Key words: historical structures of agricultural landscape (HSAL); viticulture; forms of anthropogenic relief (FAR); Rača

Received: 19 Nov 2012 - Revised form: 3 Jun 2013 - Accepted: 20 Jun 2013

\section{Introduction}

Human society and landscape have been interacting and evolving for thousands of years. They operate as a coherent system of relations and variables. Through their activities, people have altered the original landscape and simultaneously, the characteristics of landscape have limited or supported the development of human activities. Because of the mutual influence of man and the environment on Earth, unique and characteristic types of landscape have been formed. These types of landscape are now classified as the natural and cultural heritage of our civilisation. However, the present developments in science and technology, the population growth together with the need for the expansion of urban areas have been disrupting the balance between the characteristics of landscape and the needs of society. Perhaps the best example of the negative effects of man on the landscape in general is a sudden change in land use (for example an intensive suburbanisation into the rural landscape, mending of the land, deforestation, etc.). Altering the land use not only causes changes in the landscape structure and its ecological stability, but also often means the loss of the unique elements of landscape, which help people 
identify with their surroundings. In addition, reckless changes in land use not only change landscape's appearance, but also its aesthetic and valued characteristics.

Historical landscape structures are a specific subtype of landscape structures, which are characterised by time of their establishment and tend to be reduced by means of their occurrence. Huba (1988) characterises them as 'tangible and immovable parts of cultural heritage with a distinct application in space'.

The main occupation of the inhabitants of the Small Carpathian region in the past was viticulture. By means of the extent of production and the quality of wine, Rača has been one of the most important centres of viticulture in the foothills of the Small Carpathian region since feudalism. Vineyards have been established and cultivated here for centuries, mostly in places where they existed since the times of the Roman Empire. As a result, the vineyards at the SouthEastern slopes represent a preserved element of HSAL. Through long-term vineyard cultivation, unique small-scale landscape elements have been formed. These elements are specific for this region and include a variety of narrow-band terraces, stone mounds or bulwarks, small stone walls and heaps and stone vineyard sheds. Dobrovodská, et al. (2010) define them as 'forms of anthropogenic relief' (FAR).

At present, HSAL are endangered by changes in the cultivation process and land use, alterations in the spatial plans of municipalities, but especially by the lack of interest of owners of the areas where these elements occur. These tendencies cause damage and slow demise of HSAL.

In 2005, one of the most important international documents concerning the protection of natural, cultural, historical and aesthetic value of landscapes - the European Landscape Convention (ELC) - was ratified by Slovakia. One of the specific objectives derived from the ELC is to determine the 'landscape quality objective' (based on the cooperation of experts and general public), and to perform actions to conserve and maintain the significant characteristic features of a landscape, justified by its heritage value and derived from its natural configuration and/or from human activity (MZP SR 2012).
As a part of wider research, focused on sustainable development and management of historical vineyard's landscape in Bratislava region, the aim of this research is to map the current state of HSAL by using accessible maps and doing field work in the viticultural land of the cadastral territory of Rača.

\section{Methods and material}

The area of interest for the purpose of mapping the occurrence of HSAL is the cadastral territory of Rača. Rača is one of the 17 boroughs of Bratislava, the capital city of Slovakia, which is situated in its South-Western region of the country. Rača has 22 thousand inhabitants in an area of 2400 hectares (ŠtU SR 2012). The geological subsoil (mainly formed by acid crystallinic stones); lightsoils (which contain a high quantity of skeleton parts from decomposing of stone, ballast and sand); a suitable climate (with average annual temperature of 9 degrees of Celsius, in vegetative season 15 degrees of Celsius on average, and with rare frosty days when temperature goes under 20 degrees of Celsius); high amount of natural sunlight (as much as 2100 hours) and annual rainfall aggregate approximately $700 \mathrm{~mm}$ on average; relative air humidity of approximately $70 \%$; ideal orographic conditions (South-Eastern exposition of slopes with 12\% decline) - all these conditions contributed to the development of viticulture in this area for centuries (Krivosudský, 2009).

Many authors have been mapping the HSAL in Slovakia, for example Dobrovodská, et al. (2010), Slámová, et al. (2008), Huba (2004) and others. Generally, HSAL have also been mapped by foreign authors, for example Gojda (2000), Kolejka (1987), Kuna (2004), Tempesta (2010), Lipský (2000), Labuda (2011) and others. From abroad, the works of Peérés, Gaussier (2008), Antrop (2009), Hőchtl, Konold (2009), Tempesta (2010), Petit, Konold, Hőchtl (2012) are needed to be mentioned due to their focus on historical landscape structure and it's changes in rural landscapes.

The research in the cadastral territory of Rača has been based on the methodical approach of Špulerová, et al. (2009) to mapping of HSAL. 


\section{VERSITA}

According to them, HSAL are mosaic structures of extensively used small-scale landscape elements of arable land and permanent agricultural crops (permanent grassland - meadows and pastures, vineyards, tall orchards and chestnut orchards), i.e. currently unused areas with a low degree of succession. They are the remains of the original medieval and early-modern period of feudal land structure and they have been maintained till present in those areas that were not directly affected by the collectivization of agriculture in the second half of the 20th century.

The research was conducted at two levels (modified from Štefunková, et al., 2011 mapping of FAR):

1. Level of the cadastre. Level of the cadastre is the level of the entire area of the municipality. At this level, secondary landscape structure and land use trends were examined. Basic identification of historic agricultural structures, their typing and categorization was performed.

Based on the accessible materials, two time levels were analysed - year 1951 and year 2011.

- 1951 represents the period prior to collectivisation and economic and technical adjustments of landscape. Aerial metrical images from the Topographical archive of the Armed forces of Slovakia were used as the base.

- 2011 represents the current land use. It is used so that the preservation of HSAL in the area of interest from past till present can be evaluated. Images from Google Earth were used as the base.

The underlying raster data were further processed in the GIS environment (ArcGIS in. 9.3), using the methodology of Boltižiar, Olah (2009). Through the "on screen" method, elements of landscape structure were identified. Vector maps with the database table were created. The elements of landscape structure were divided into 8 groups (according to the work of Pucherová et al. 2007).

2. Level of the research sites. The research sites contain an area of several acres. These were established in order to represent the basic types of HSAL. Each research site is a mosaic of different historical landscape elements production parcels of differentiated land use and the intensity of its use, i.e. overgrowing and various types of historical forms of anthropogenic relief with different properties. During the reconnaissance in the field, the status of individual elements was mapped and photographic documentation was created.

\section{Results}

The results of the analysis on the level of the cadastre are shown on maps of landscape structure for 1951 and 2011. For 1951, it was possible to identify 141 localities of HSAL. These were mainly located in the North-Western part of the area of interest, which mostly consisted of the mosaic of vineyards, orchards and gardens. The vineyards used to have a down the slope line orientation and they were formed by narrowband fields. For 2011, the number of identified localities fell from 141 to 25 . The HSAL localities were mainly preserved in the marginal areas between vineyards and forests, and on the horticultural sites. The vast majority of preserved vineyards were terrace areas formed of large blocks, that were contour line oriented, supplemented by unpaved access roads and nonforest woody vegetation on the slopes of the terraces. Fig. 1 shows the occurrence of HSAL in both 1951 and 2011.

Based on the HSAL localisation during the level of the cadastre analysis, the field work and mapping of the current HSAL occurrence was conducted for the level of research sites analysis. 25 localities were found. The following forms of anthropogenic relief (FAR) were present:

- Stone mounds - at 14 sites,

- Stone heaps - at 6 sites,

- Low stone walls - at 9 sites,

- Narrow-band small-scale terraces - at 9 sites and Stone vineyard sheds - at 8 sites.

A stone mound, also known as „rúna” (Fig. 2a) was present at 14 sites. Stone mounds were established during the cultivation of land by human activity. During the process, large and medium pieces of stones were intentionally removed from the soil. This process is related to using plough when cultivating the soil. Unused stones were collected and stored in on the edges of the land area (in order to serve as a boundary between two parcels), or in the contact area of 


\section{VERSITA}

farmlands and the forest. These stones also could have been used as a heat accumulator, collecting heat from the sun, or an artificial windbreak. In both cases, this type of stone use had a positive influence on the culture of the grape. In the past, fruit trees were planted on the stone mounds (if they contained soil as well) or in their close proximity. A variety of high stone mounds was created through successive layering. When there was no further layering process, tree and shrub vegetation started to grow on these mounds.

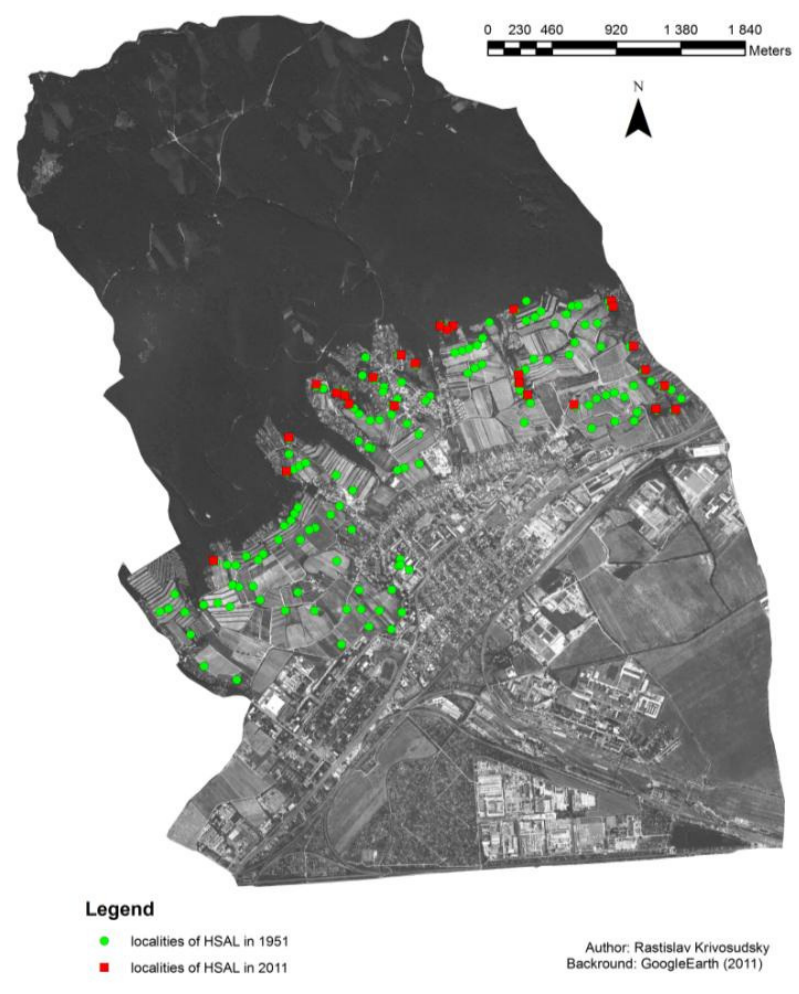

Fig. 1a: Presence of the HSAL in cadastral area of Rača village in the years 1951 and 2011.

Stone mounds have been preserved till present mainly on steeper slopes in gardening and cottage areas. They are mainly covered by soil and growing vegetation. The remnants of stone mounds in the areas on the edge and in side of the forest were identified on 6 sites. This is because of the occurrence of vineyards in the past - they were planted in higher elevation, and are now part of the forest land.

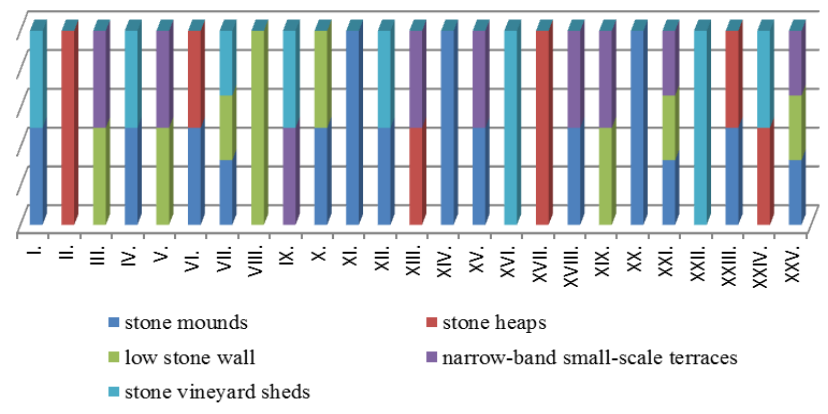

Fig. 1b: Presence of identified FAR on 25 localities of HSAL (author: R. Krivosudsky, 2011)

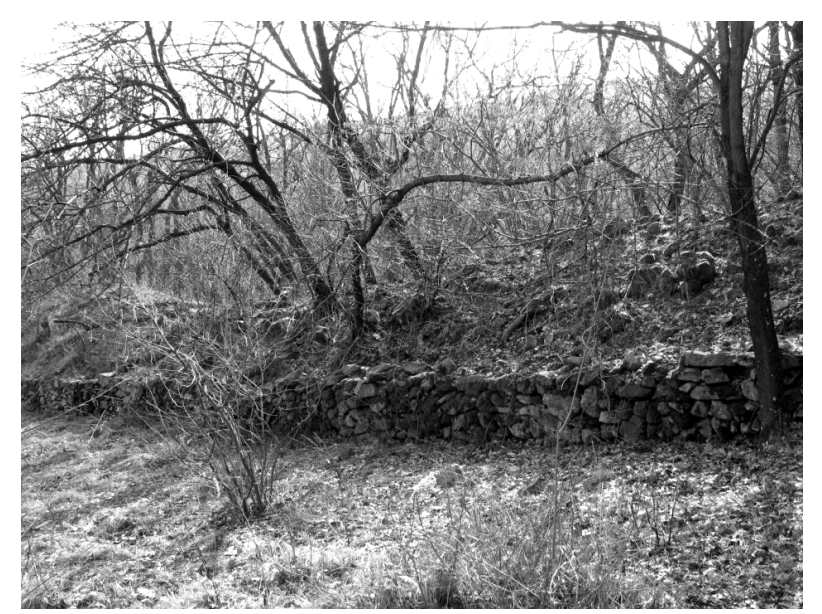

Fig. 2a: Stone mound (author: R. Krivosudsky, 2011)

Stone heaps were found in 6 locations, mostly in areas that are not used, and in the marginal area between gardens and the forest. In the past, their emergence was the same as the process of the establishment of stone mounds - "rúna". Stones, which had been dragged out from soil, were not stored on bulks (as opposed to stone mounds), but on the "unused areas", or drifted into the forest massif. Currently, stone heaps, similarly to stone mounds, are covered by soil and vegetation.

Low stone walls, which were located on 9 of the sites mapped, were used as a support system for the terraced fields. They balanced out the terrain elevation between the respective terraces and also prevented landslide at the same time. During the fieldwork, 2 types of low stone walls were identified - consolidated and unconsolidated. Like mounds, low stone walls (Fig. 2c) could have served as heat accumulators and had positive impact on grape growth. At present they are part 


\section{VERSITA}

of gardening areas, along with small-scale terraces. The majority of low stone walls are consolidated by recent concrete. 3 abandoned and successively overgrown sites were preserved in their original state. In the model area, their remnants can be seen in relation to sunken lanes, which are unpaved roads that go down the slope line.

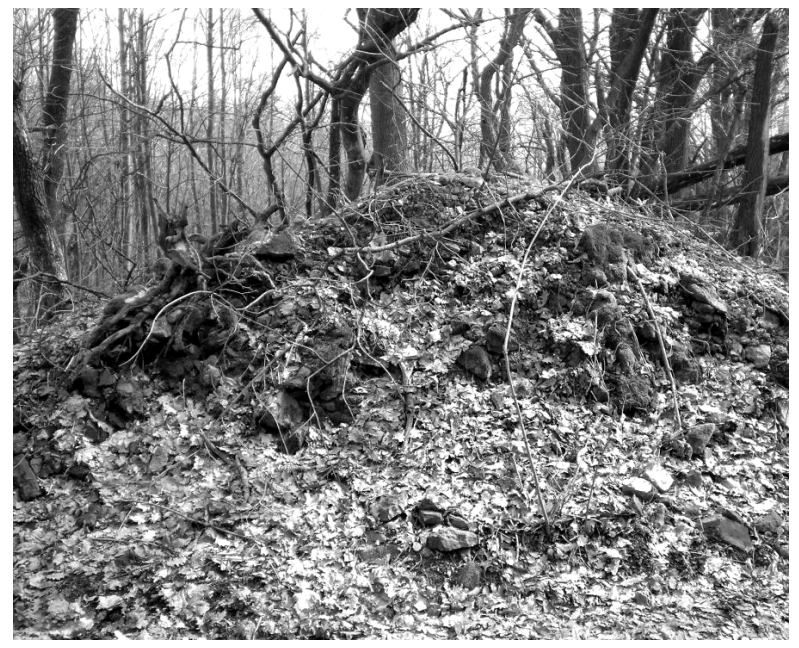

Fig. 2b: Stone heap (author: R. Krivosudsky, 2011)

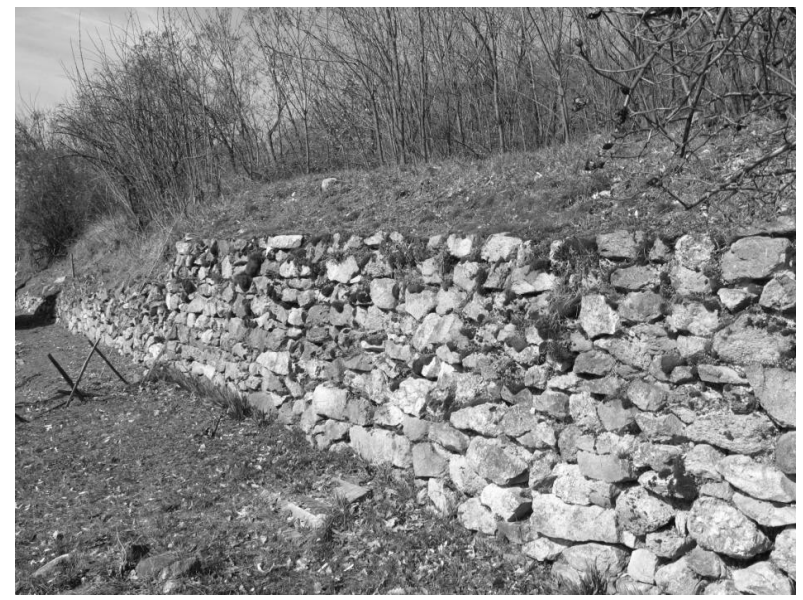

Fig. 2c: Low stone wall (author: R. Krivosudsky, 2011)

Narrow-band small-scale terraces (currently identifiable at 3 sites) represent one of the main ways of how people dealt with adverse morphological conditions of the terrain in the past. They also served an anti-erosion purpose. Their presence was closely related to the occurrence of low stone walls, where the low stone walls were components of the terraces and served as their support system.
In the past, most of the model area, whose slope of the relief exceeded 15\%, was formed by narrow-band terraces (Fig. 2d). These terraces are currently only present in the marginal zones of large vineyards and forests. They are a part of gardening and cottage areas. The orientation and size of the areas is preserved for the most part, but their type of use has changed.

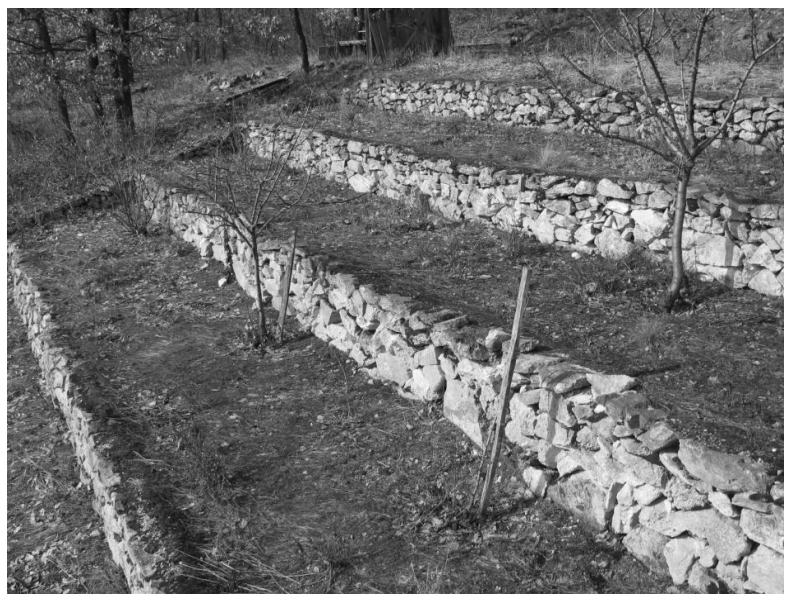

Fig. 2d: Narrow-band small-scale terrace (author: R. Krivosudsky, 2011)

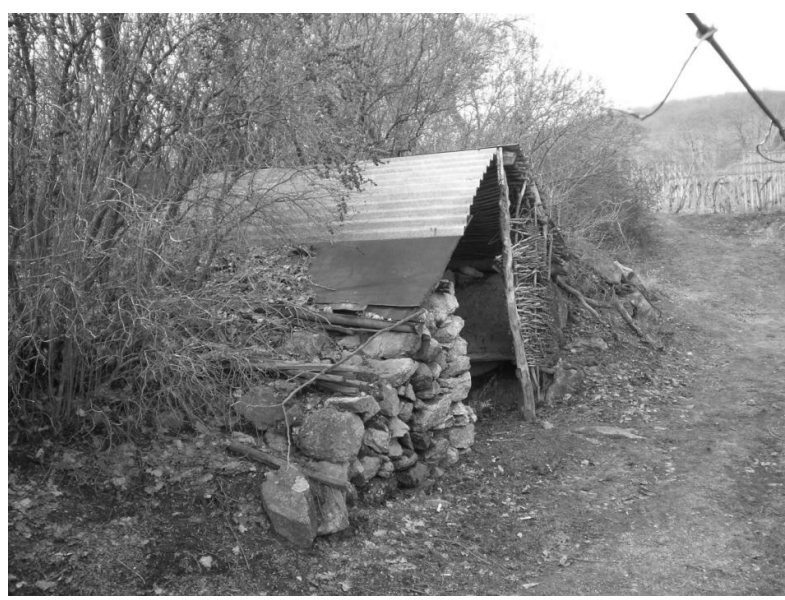

Fig. 2e: Stone vineyard shed (author: R. Krivosudsky, 2011)

Stone vineyard sheds (Fig. 2e) served as a shelter for people in case of bad weather, as a resting place, or as storage of tools. Only torsos of these have been preserved till today on 6 sites in the form of outside walls alone or with part of the wooden roof. It was possible to see the overall building structure at two sites, due to the continuity of its usage. Vineyard sheds were built from the same material as stone mounds and low stone walls and they were usually located in close 


\section{VERSIT $\Lambda$}

distance to mounds, or they were a part of the mounds themselves. The roof was mostly built up from hard, raw elaborated wood - mainly of thick branches, covered with straw or wood shingles. The floor plan of these sheds was often a square with a support beam for the roof in the middle. The floor was made of clay, rarely from loosely placed flat stones.

\section{Discussion}

The mapped elements of HSAL represent the changes which occurred in Rača in the second half of 20th century in terms of their frequency, physical condition and current use (as shown in Figs. $3 a$ and $3 b, 4 a$ and $4 b, 5 a$ and $5 b$ ). The onset of collectivisation caused that the fragmented areas of respective owners had been merged into large areas. Collectivisation was followed by an era of economic-technical adjustments of the parcels, which persisted into the 1980s. These adjustments meant that the old vineyards were grubbed and the bulks between the parcels were ploughed. In addition, a large part of the original "abandoned areas" such as stone mounds and stone heaps were removed or became a basis for creation of new large block terraces. The large block terraces were often created by combining several narrow-band terraces. These amendments were intended to enable machine vineyard management. The new wired outplanting unit became one varietal (as opposed to mixed outplanting of the stick vinyerads in the past). Small terraced areas are established on more steeper slopes.

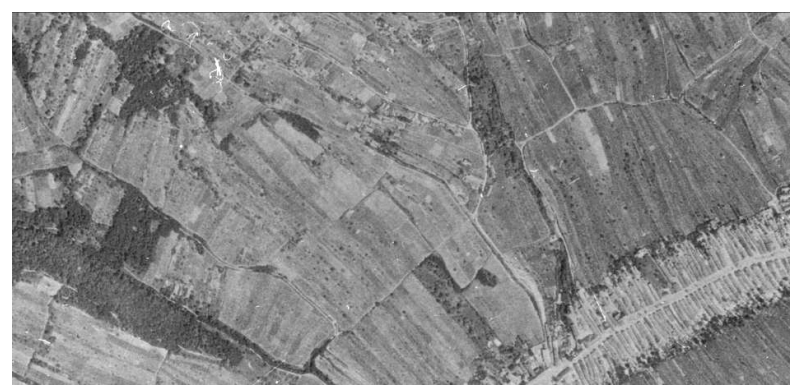

Fig. 3a: Sample of aerial photo reflecting land use in locality "Fixle" and "Lichtky" in 1951

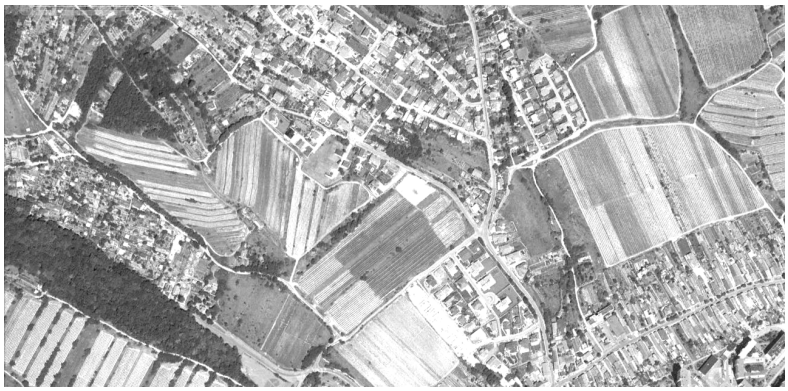

Fig. 3b: Sample of aerial photo reflecting land use in locality "Fixle" and "Lichtky" in 2011

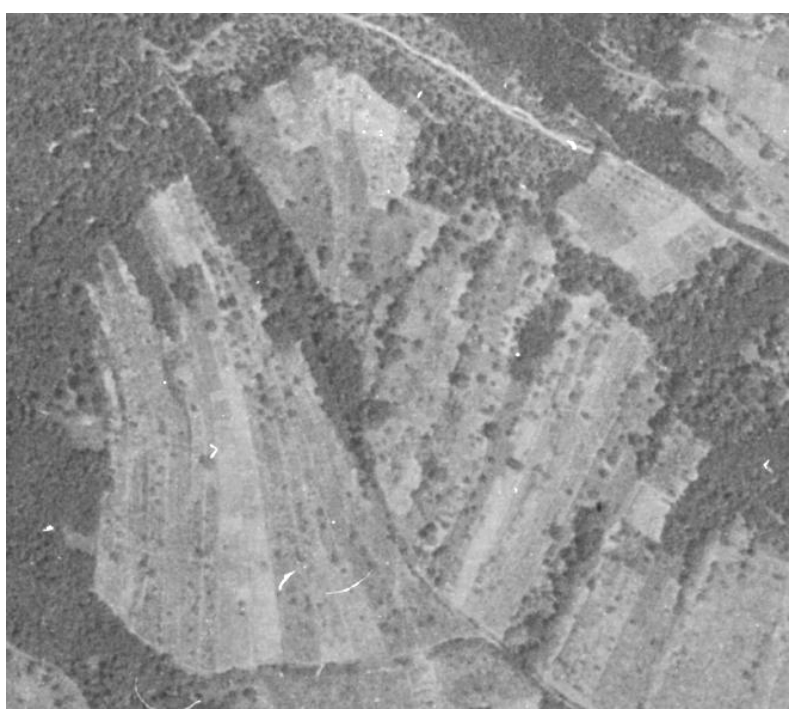

Fig. 4a: Sample of aerial photo reflecting land use in locality "Nová hora" in 1951

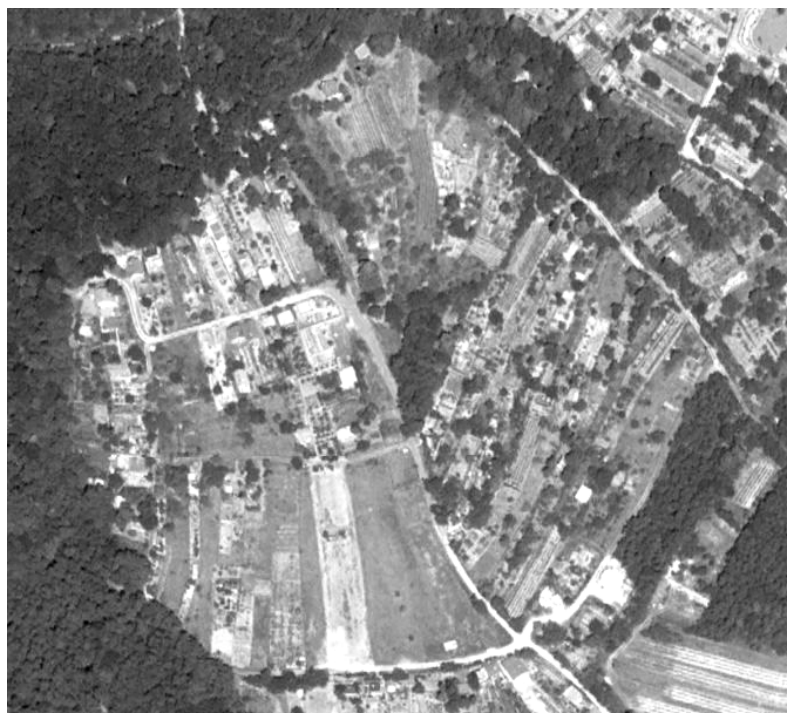

Fig. 4b: Sample of aerial photo reflecting land use in locality "Nová hora" in 2011

In the marginal zone between forest and the vineyards, in areas with rough terrain and around 


\section{VERSITA}

stream banks, gardening and cottage areas were established, because merging of the land would not be effective. This enabled the parcel orientation and many of the aforementioned elements of HSAL to be preserved. However, because of the rapid increase in the pressure of suburbanisation into the surrounding, originally rural landscape at the beginning of 21st century in Bratislava, also these HSAL elements have been converted into residential buildings. This change has caused a gradual elimination of "unnecessary" stone mounds, low stone walls and terraces.

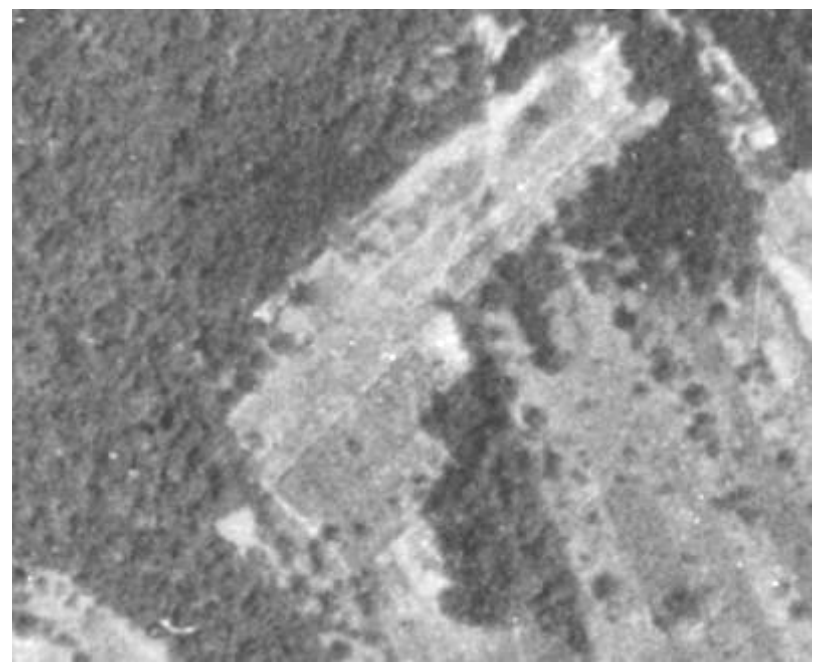

Fig. 5a: Sample of aerial photo reflecting land use in locality "Komandl" in 1951

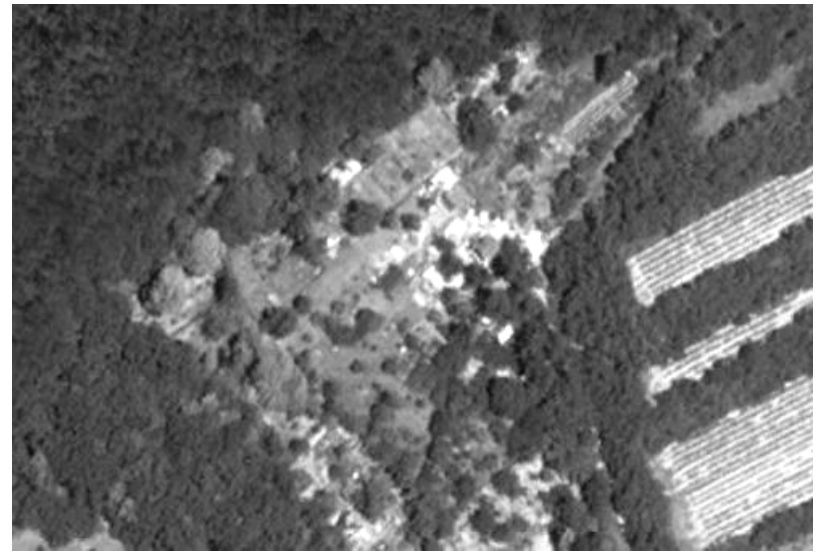

Fig. 5b: Sample of aerial photo reflecting land use in locality "Komandl" in 2011

By means of future research, it is advisable to complement the mapping of these anthropogenic forms of relief in Rača by an analysis of its basic characteristics, such as: concentration of hard parts in them, their height, width, spatial continuity of FAR, biotope, continuity of woodland, concentration of its coverage by vegetation layers (in \%) and to compare the results with research in surrounding vineyard sites with similar historical development and abiotic conditions. A detailed research of $\mathrm{HSAL}$ was carried out for the Svätý Jur municipality, which is located approximately 2 kilometers from the Rača border. It would be interesting to compare both attributes of the individual elements, as well as their ownership attributes, their location and a feasible protection system of these rare and ever-shrinking areas.

\section{Conclusion}

The research about HSAL in the cadastral area of Rača has shown evidence of the still present original forms of anthropogenic relief. In spite of the significant changes of landscape from the 1950s till present, the unique characteristics of wine culture were preserved. Based on the analysis of maps of landscape structure in 1951 and 2011 and field work, 5 forms of HSAL were identified. They are connected to the history of viticulture and viniculture and to the traditional forms of cultivation of the South-Eastern slopes of Small Carpathian area. The $5 \mathrm{HSAL}$ forms include stone mounds - „rúna“, stone heaps, low stone walls, narrow-band terraces and vineyard sheds. These forms represent a preserved cultural heritage and only 25 localities out of the original 141 were preserved, mainly in areas where collectivisation did not take place in the second half of the 20th century. However, at present they are endangered by the pressure of changes in land use. Their protection under the legislation of Slovak republic is not established, as there are no official methodical approaches to its research. The results of ongoing research are not being incorporated into the law concerning spatial planning. The countries which ratified ELC have committed to preservation of their unique elements, which are an important part of the cultural and social heritage of mankind. As a result, it is necessary to develop a tool that implements this goal and ensures protection of the aforementioned areas. 


\section{Acknowledgements}

This paper is prepared under project VEGA No. 1/0544/11 "Landscape-ecological evaluation of historical structures of agricultural landscape" and project VEGA No. 1/1139/11 "Changes of landscape connectivity in the contact zone of Small Carpathian Mts. and adjacent lowlands" with translation support by Miss Sona Zemanova.

\section{References}

Antrop M (2009) Indicators for assessing changing landscape character of cultural landscapes in Flanders (Belgium). Land Use Policy 26(4): 901-910.

Boltižiar M, Olah B (2009) Krajina a jej štruktúra mapovanie, zmeny a hodnotenie. Univerzita Konštantína Filozofa v Nitre, Nitra.

Dobrovodská M, Špulerová J, Štefunková D (2010) Survey of historical structure of agricultural landscape in Slovakia. In: Pedroli B, Agnoletti M (eds.) The European Landscape Convetion in research perspective (conference materials), Vol. 1, Florence, pp. 88-92.

Gojda M (2000) Archeologie krajiny. Vývoj archetypů kulturní krajiny. Academia, Praha.

Höchtl F, Konold W (2009) Historische Terrassenweinberge: Landschaftselemente in Harmonie von Natur und Kunst. In: Journal Culinaire 8: 10-16.

Huba $M$ et al. (1988) Historické krajinné štruktúry. Ochranca prírody, MV SZOPK, Bratislava, pp. 1-5.

Huba M (2004) Historické štruktúry krajiny v kontexte súčasnej reality. Životné prostredie 38(2): 86-89.

Kolejka J (1983) Landscape - historical synthesis. Material, methods and results. Ekológia (ČSSR) 6(1): 51-62.

Krivosudský R (2009) Hodnotenie vývoja a súčasného stavu vinohradov v k.ú. Rača. Diplomová práca, Katedra krajinnej ekológie PRIF UK, Bratislava.

Kuna M et al. (2004) Nedestruktivní archeologie. Academia, Praha.

Labuda M (2011) Sadové lúky - špecifický typ biotopu a ich význam v kultúrnej krajine. Acta Facultatis Ecologiae 24-25: 79-89.

Lipský Z (2000) Sledování změn v kulturní krajiine: učební text pro cvičení z předmětu Krajinná ekologie. Česká zemědelská univerzita, Praha.

MZP SR (2012) Oznámenie Ministerstva zahraničných vecí Slovenskej republiky č. 515/2005 Z.z. Európsky dohovor o krajine. dostupné na: [http://www.minzp.sk/eu/medzinarodne- dohovory/europsky-dohovor-krajine-europeanlandscape-convention/]

Peérés J, Gaussier N (2008) Vineyard Land Use Change in Residential Use:An Empirical Investigation of the Bordeaux Urban Fringe. In: Territoires et action publique territoriale: nouvelles resources pourle développement régional - sbornik z konferencie, Universitédu Québec, Canada, pp. 123-136

Petit C, Konold W, Höchtl F (2012) Historic terraced vineyards: impressive witnesses of vernacular architecture. Landscape History 33(1): 5-28.

Pucherová $Z$ et al. (2007) Druhotná krajinná štruktúra - metodická príručka k mapovaniu. Univerzita Konštantína Filozofa v Nitre, Nitra.

Slámová M, Jančura $\mathrm{P}$, Kul'anda $\mathrm{M}$, Jakubec B (2008) Historické krajinné štruktúry v pohorí Ostrôžky. In: Benčat' $T$ et al.: Vybrané problem krajiny podhorských a horských oblastí. Partner, Poniky, pp. 61-68.

Špulerová J, Štefunková D, Dobrovodská $M$ et al. (2009) Príručka na mapovanie historických krajinných štruktúr pol'nohospodárskej krajiny. UKE SAV, Bratislava.

Štatistický úrad SR (2012) Štatistická ročenka hl. m. SR Bratislavy, ŠU SR, Bratislava.

Štefunková D, Dobrovodská $M$, Kanka R, Krnáčová $Z$ et al. (2011) Atraktivita Malokarpatskej krajiny s dôrazom na historické agrárne štruktúry a biodiverzitu. UKE SAV, Bratislava.

Tempesta T (2010) The perception of agrarian historical landscapes: A study of the Veneto plain in Italy. Landscape and Urban Planning 97(4): 258272. 